Baillarger and J. P. Falret, and the busts of Pinel and Esquirol at Toulouse, are written in impeccable French and breathe a severely classic spirit.

He was the recipient of many marks of distinction, including the Legion of Honour, the presidency of the Congress of French-speaking Alienists and Neurologists, the presidency of the Clinical Society of Mental Medicine, and the presidency of the Mutual Association of French Alienists.

He died, after a brief illness, at the villa at Auteuil, to which, on leaving the Maison Nationale, he had retired, where neither Gothas nor Berthas had ever succeeded in driving him from among his books. He bequeathed 20,000 francs to the Mutual Association of French Alienists, and the residue of his fortune to the Academy of Medicine and other learned bodies for the founding of prizes in mental medicine.

Peculiarly appropriate to Ritti himself are the noble words in his eloge of Calmeil : "Ennemi du faste et du bruit, Calmeil nous lègue à tous l'exemple de ce que peuvent, pour le progrès des connaissances et même pour le bonheur individuel, le gout de la retraite, la passion du savoir et l'amour de la vérité. Puisse ce modêle si achevé du médecin aliéniste modeste, consciencieux, esclave du devoir, trouver de nombreux imitateurs, au grand profit de la science et de l'humanité."

David Yellowlers, M.D.Edin., LL.D.Glasg.

THE recent decease, full of years and honours, of Dr. David Yellowlees removes from our midst one of the few remaining pioneers of the renaissance which occurred in British psychiatry during the later decades of. the nineteenth century.

Reference was made to his personality and career by the President, Dr. W. F. Menzies, at the Quarterly Meeting of the Association in February, and also by Dr. R. B. Campbell at the March meeting of the Scottish Division. We hope to publish an extended biography in a future number of the Journal.

The Lancet in its obituary notice (February 5th, 1921) says :

"With the death of Dr. Yellowlees at Edinburgh, on January 19th, in his eighty-fifth year, has passed away a man who combined high professional attain. ment in mental medicine with a gift for administration. David Yellowlees was born and brought up at Stirling, graduated at Edinburgh in 1857, and after a period of study abroad returned as assistant to Sir William Gairdner at the Edinburgh Royal Infirmary. His first appointment in psychiatry was to assist Dr. Skae at the Edinburgh Royal Asylum, Morningside, and in 1863 he went to direct the Glamorgan County Asylum, where he remained twelve years. In 1874 he followed Dr. Mackintosh as Physician-Superintendent to the Royal Glasgow Asylum, Gartnavel, a post which failing eyesight obliged him to relinquish in $190 \mathrm{r}$. During the greater part of this tinie he lectured on insanity in the University of Glasgow, which conferred upon him the honorary degree of LL.D. in 1888. He presided over the Psychological Section of the British Medical Association which met at Glasgow in 1885, over the Medical-Psychological Association in 1890, and over the Faculty of Physicians and Surgeons of Glasgow in 1892-94.

"Under Yellowlees Gartnavel became a keen centre of psychiatric thought. His physical energy and enthusiasm, combined with a radiant optimism, infected his assistants, as well as in some measure the patients and their friends. His routine was to entrust each of his helpers with the entire responsibility of a part of the asylum, and to hear and discuss their reports at his own house every day at noon. He then visited the wards independently, acting as a kindly and sagacious consultant. Simple and frank himself, he expected, and generally found, the same qualities in others, who grew to rely upon his honest and fearless character.

"Dr. Yellowlees took a leading part in the philanthropic work of the city which became his second home. He was for the greater part of his active life on the directing board of the Association for the Relief of Incurables, the Brambill Home for Incurables, and the Lanfine Home for Consumptives. He helped to found the Glasgow Association for the Care of Defective and Feeble-minded Children, and 
warmly supported the Glasgow Medical Missionary Society. Work for the protection of women and children always found in him a good friend. All these things were the outcome of deep religious conviction.

"After his retirement in 1901 Dr. Yellowlees continued to live in Glasgow until the autumn of 1919, when he returned to Edinburgh to spend the last eighteen months of his life. He is survived by his wife, a daughter and two sons, both of whom are in the medical profession. Dr. David Yellowlees is in practice in Stirling; Dr. Henry Yellowlees is Senior Assistant Physician to the Royal Edinburgh Asylum."

The following is an appreciation from the pen of Sir George Savage:

"Now the father of the Association has gone, and only few survivors of the old brigade remain to recall the earlier and more active connection of Yellowlees with our body. I believe before the Association had a corporate existence that some of the northern superintendents used to meet at each other's asylums for social reunions. I believe Yellowlees with Ley Rogers, Mould and Clouston formed the centre of this union, but this is very long ago and before my time. Elected a Member of the Association in 1862 , he was a very regular attendant at the meetings, whether in Scotland or England. He generally spoke briefly and to the point, and he always carried weight. He was a true Scot, and his genial welcome and his humour did everyone good to meet him, for though strong in his views and willing to support them, he was not a man of one view. I shall not speak of his professional work; this will be for some compatriot to enlarge upon. Personally I was always attracted by him. He was happily married and proud of his family. I do not think that he was given to sport; his life seemed to be too full of work for the fringes of games to come in. He belonged to the old convinced religious school of thought, and his religion was a real part of his life. With advancing years he slowly lost his sight, but this did not prevent him from continuing his useful social work or even from attending some of our meetings. There was no crying over his fate : he accepted it in a truly Christian Spirit. So he lived in the memory and affection of his friends, and now leaves a savour of sweetness and light which we may well envy."

\section{THE ASSOCIATION LIBRARY.}

Mrmbers of the Association are reminded that the Library at II, Chandos Street, W., is open daily for reading and for the purpose of borrowing books. Arrangements have been made with Messrs. Lewis to enable the Association to obtain books from the Lending Library belonging to that firm should any member desire a book not in the Library. The following medical periodicals are circulated amongst such members as intimate their desire to have them:

The American Fournal of Insanity.

The International Fournal of Psychoanalysis.

Gournal of Neurology and Psycho-Pathology.

L'Encephale.

Application for books should be addressed to the Resident Librarian, MedicoPsychological Association, II, Chandos Street, Cavendish Square, W.

Other communications should be addressed to the undersigned at the City of London Mental Hospital, Dartford, Kent.

R. H. Stren Secretary to the Library Committee.

\section{NOTICES BY THE REGISTRAR.}

\footnotetext{
Nursing Certificate. - The next examinations will be held as follows :

Preliminary . $. . \quad . \quad . \quad . \quad . \quad . \quad M a y ~ 2 n d, 1921$. Final
} 